\title{
МЕЖПАРАДИГМАЛЬНЫЙ ПЕРЕХОД В СТРУКТУРЕ И ОРГАНИЗАЦИИ МЕЖДУНАРОДНОЙ ЖИЗНИ
}

\section{Шедяков В. Е.}

Сам капитализм деградировал и сомёл с ума, потому что мы сами же порождаем те проявления неравенства, урегулировать которые мы потом не в состоянии.

Э. Макрон

\section{ВВЕДЕНИЕ}

Международная жизнь радикально переформируется (в том числе манипулятивными средствами). Кардинальное переструктурирование глобального мироустройства уже преодолело свою «точку невозврата» ${ }^{1}$. Стали вполне заметны не только основные варианты решений, но и главные черты нового устройства международной архитектоники, тесно связанные с характеристиками внутренних трансформаций ${ }^{2}$. Канут в прошлое приметы прежнего мирового порядка, невзирая на ожесточённое сопротивление его фаворитов ${ }^{3}$. В проявившихся тенденциях сливаются потоки самоорганизации и целенаправленного воздействия разных (в частности, государств и надгосударственных союзов) сил, воль личностей и организаций, циклично повторяемых и безвозвратно уникальных процессов. Во время межпарадигмального перехода турбулентность, естественно, нарастает, - причём ныне это происходит стремительно и многоуровнево ${ }^{4}$. Но вот направленность, пути, формы, темпы, следовательно, результаты трансформаций могут быть различными как

1 Энгель У. Боги денег. Уолл-стрит и смерть американского века. СанктПетербург : Питер, 2011. 326 c.

2 Кобяков А.Б., Хазин М.Л. Закат империи доллара и конец "Рах Americana". Москва : Вече, 2003. 368 с.

${ }^{3}$ Engdahl F.W. A Century of War: Anglo-American Oil Politics and the New World Order. Pluto Press, 2004. 312 p.

${ }^{4}$ Gamble A. Crisis Without End? The Unravelling of Western Prosperity. UK: Palgrave Macmillan, 2014. 240 p. 
для разных групп населения, так и стран ${ }^{5}$. И дело отнюдь не только в потенциале как таковом, но и в умении распорядиться им в меняющихся условиях: не мнимые угрозы фантомных представлений, а настоящие проблемы требуют консолидированных усилий народов ${ }^{6}$.

И повышение эффективности использования каждым субъектом международных экономических отношений своего потенциала, высвобождение преимуществ и компенсации недостатков / уязвимостей предполагает сознательность и скоординированность усилий ${ }^{7}$. При этом совсем не обязательно включать и поглощать, чтобы управлять и контролировать ${ }^{8}$. Между тем часто те, кто полагают, будто обладают «золотой акцией» и контролируют процессы, расслабляются - и проигрывают ${ }^{9}$. Ныне сохранение реальной глобальной субъектности (а не превращение в объект внешнего манипулирования) тем более требует понимания существа международных процессов и диапазона эффективных воздействий на него для реализации своих законных интересов ${ }^{10}$. Успешными становятся в первую очередь те культурно-цивилизационные миры, которые в состоянии не только заинтересовать, увлечь своими смыслами, но и структурировать своё социальное пространство, применяя при этом и классические и инновационные ресурсы, интегрируя базисные для себя формы ценностного сознания с логикой исторических изменений. Культивирование Сверхпроекта, кластеров развития, благотворного для желанных перемен социального климата важные факторы использования уникальных возможностей переходного периода, укрепляемые единством сознательного целеполагания с объективными трендами социально-экономической

5 Фурсов А.И., Правосудов С.А. На пороге глобального хаоса. Битва за будущее. Москва : Книжный мир, 2015. 288 с.

${ }^{6}$ Хамел Г., Прахалад К. Конкурируя за будущее. Москва: Олимп-Бизнес, 2002. 216 c.

${ }^{7}$ Блэквилл Р., Харрис Дж.М. Война иными средствами. Москва : АСТ, 2017. $480 \mathrm{c}$.

${ }^{8}$ Откуда исходит угроза миру. Москва : Воениздат; Прогресс; АПН. 3-е изд. $1984.96 \mathrm{c}$.

${ }^{9}$ Калаич Д. Третья мировая война. Москва : Литератор, 1995. 156 с.

${ }^{10}$ Амин С. Вирус либерализма: перманентная война и американизация мир. Москва : Европа, 2007. 162, [6] С. 
динамики ${ }^{11}$. Так, народы, живущие на территории Украины, когда-то естественным образом сложились в ядро Советского Союза, сформировав его организационно-управленческую модель. Украинская ССР участвовала изначально в Союзном Договоре, а затем её представитель занимал место в числе постоянных членов Совета Безопасности ООН. И с разрушением СССР Украине досталась одна из мощнейших экономик Европы, лучший в Советском Союзе научнопромышленный баланс (треть ВПК СССР и обширная патентная база), завидная обеспеченность (как абсолютная, так и подушевая) ведущими сырьевыми запасами и профессиональными кадрами, а также сконцентрированность производств, транзитные возможности и т.д. ${ }^{12}$.

Свои размышления о более гармоничном устройстве международной жизни формулировали и искали пути их осуществления такие национальные герои и выдающиеся государственные деятели, как Ж.-Р. Эбер и П. Г. Шометт, Ж. Ру и Ж.-Т. Леклерк, Г. Бабёф и А. Сен-Симон, А. Ордин-Нащокин и В. Голицын, А. Горчаков и А. Бестужев-Рюмин, А. Грибоедов и А. Пушкин, Г. Потёмкин и А. Безбородко, Г. Сковорода и А. Панин, Г. Шелихов и Н. Резанов, П.-Ж. Прудон и К. Маркс, С. Боливар и Х. де Сан-Мартин, П. Вилья и Э. Сапата, А. Сандино и Ф. Марти, Г. Чичерин и А. Громыко, Э. Че Гевара и Ф. Кастро Рус, Д. Ортега Сааведра и С. Альенде, Хо Ши Мин и П. Лумумба, Ш. де Голль и Д. Стросс-Кан. Возможности и условия создания, закрепления и переформатирования установок, способных выстраивать под себя реакции и создавать рефлексы, исследовали И. Павлов, А. Ухтомский, Дж. Овертон, М. Лангштейн и прочие. Проведённое исследование базируется также, во-первых, на характеристике сущности и вектора изменений международных отношений Ж. Алфёровым, Ж. Аттоли, Э. Бабиным, У. Беком, Г. Бехманном, А. Богатуровым, А. Бузгалиным, В. Букреевым, А. Бутенко, В. Вазюлиным, И. Валлерстайном, А. Вассерманом, В. Волгой, В. Геецем, Э. Гидденсом, С. Глазьевым, Л. Градобитовой, А. Гринспеном, А. Громыко, Ф. Дваири, А. Дугиным,

11 Шедяков В.Е. Возможности и риски эпохи: научно-исследовательская рефлексия - рефлексивное управление - рефлексивная модернизация. Management of modern socio-economic systems / ed. by J. Žukovskis, K. Shaposhnykov. Kaunas : Baltija Publishing, 2017. Vol. 1. P. 201-218.

12 Швейцер П. Тайная стратегия развала СССР. Москва : Эксмо; Алгоритм, 2010. 304 c. 
А. Зиновьевым, А. Иголкиным, Р. Ищенко, Д. Калаичем, С. Карагановым, М. Кастельсом, А. Киреевым, Г. Киссенджером, А. Колгановым, В. Корниловым, А. Коробкиным, Н. Косолаповым, С. Кургиняном, С. Миллером, С. Михеевым, В. Мотылёвым, И. Носковой, К. Овчинниковым, А. и И. Панариными, В. Пякиным, В. Рыбалкиным, Н. Стариковым, М. Смитом, Б. Супруновичем, Р. Хасбулатовым, С. Хелемендиком, М. Хрусталёвым, Н. Черкасовой, К. Шмиттом, во-вторых, на выделении основных черт новых тенденций общественной жизни Е. Авдокушиным, С. Бартеневым, А. Белорусовым, Е. Брагиной, А. Булатовым, С. Бэнноном, В. Виноградовым, Р. Волковым, Э. Гэмблом, М. Делягиным, И. Джохадзе, В. Дрожжиновым, Ю. Дроздовым, В. Ефимовым, В. Железновой, Л. Ивашовым, М. Ильиным, В. Иноземцевым, Е. Касаткиной, В. Колесовым, Дж. Корбином, И. Коротченко, Дж. Куртом, М. Лебедевой, Э. Либановой, В. Ломакиным, А. Ляменковым, М. Маляровой, Р. Нисбетом, И. Острецовым, М. Осьмовой, В. Паньковым, Ю. Пахомовым, С. Пенкиной, С. Платоновым, В. Пресняковым, В. Роговым, Б. Сандерсом, В. и Н. Сапичами, К. Семёновым, С. Солнцевым, Е. Талызиной, Дж. Урри, П. Цыганковым, В. Чекуровым, О. Четвериковой, О. Шпенглером, К. Ясперсом, в-третьих, на анализе возможностей продуктивного регулятивного воздействия на них и применения появляющихся инноваций Дж. Гэлбрейтом, С. Кара-Мурзой, В. Катасоновым, С. Кравченко, С. Переслегиным, К. Петровым, В. Сагатовским, Б. Сандерсом, Е. Спицыным, Э. Уоррен, С. Ураловым, П. Фейерабендом, Ж. Фреско, А. Фурсовым, М. Хазиным, А. Этциони.

Цель публикации - выявление и анализ перспектив постглобального межпарадигмального перехода в структуре и организации международной жизни.

\section{1. Постглобальность как структура всемирных изменений}

Форсировано взламывается прежний политико-экономический уклад, сделавший невозможным дальнейшее развитие человечества как целого. Причём катастрофичность для общества сохранения в неизменном виде нынешнего состояния как социально-политического остова существующего образа жизни, так и правящей надстройки 
осознана повсеместно ${ }^{13}$. Системный мировой экономический кризис начала 21 века - проявление общего кризиса доминантной формы индустриализма, однако её преодоление неизбежно требует учёта постиндустриальных перспектив экономики знания, а также диапазона возможностей в развитии и активизации субъективного фактора ${ }^{14}$. И расцвет товарного фетишизма - это не только апология денег, но и расчеловечивание общественной жизни. Вместе с тем, не только декларирование, но и действительное следование абстракциям чистого рынка, совершенной конкуренции, свободного ценообразования, открытого общества и так далее - отнюдь не предохраняет от исторического тупика и неэффективности выбора. Редукция как к травянистому существованию, так и к животным инстинктам, реализации принципов консьюмеризма и накопительства - путь деградации человека и нарастающей атомизации общества контрмодерна. Возникающий постглобальный мир - это гораздо более сложное образование, чем ранее привычные структурирования ${ }^{15}$. Речь идёт о новых типах организационного устройства, снятии жёстких границ, мозаичности процессов, сочетании разных элементов власти. Между тем, многополюсный и разноскоростной мир, самоценность совершенно отличных друг от друга культурно-цивилизационных миров, нетерпимость к попыткам внешнего диктата и отторжение империалистического культуртрегерства: всё это (и многое другое) приметы кардинальных трансформаций, связанных с усилением постглобального устройства мира, умение жить и развиваться в котором становится приоритетным фактором стратегической конкуренции между культурно-цивилизационными мирами. Разумеется, некоторые объективные и субъективные основания постглобальности формировались и накапливались давно. Однако их комплексность и её определяющее значение - явление для ойкумены новое.

Парадигмальность перехода заключается в гораздо более существенном изменении, нежели движение от преобладания одной модели жизнеустройства к другой. Сама постсовременность также

${ }^{13}$ Burns T.R., Dietz T. Revolution: An Evolutionary Perspective. International Sociology. 2002, dec. Vol. 16. № 4. P. 531-555.

14 Шедяков В.Е. Парадигмальный переход в теории и на практике: стратегический дизайн форсированных трансформаций. Науковий вісник Херсонського державного ун-ту. Економічні науки. 2017. Вип. 23. Ч. 1. С. 54-58.

15 Шедяков В.Е. Постглобализм как социально-экономическое явление. Pyxes. 2016. № 4. C. 104-114. 
означает уход в прошлое однозначных подходов, простых моделей и «чистых» форм их воплощений - в том числе и в аспектах самовыражения и конкурентоспособности. Причём происходят изменения не только отдельных социально-политических институтов, но и всей культурной среды, отношений, структур. Дрейф к логике постмодерна (в частности, постглобализма), к логике свободы является, одновременно, отказом от единственности любого базиса развития. Уходит в прошлое оптимальность какого-либо шаблона; от конкуренции в овладении единственной моделью человечество переходит к состязанию принципиально разнокачественных подходов. Так что мировые трансформации приобретают поистине кардинальный характер. Вместе с тем, переход к реализации вариантов модели «ризома» характерен для наложения черт постиндустриальности, постглобальности и, в целом, постсовременности именно потому, что позволяет и расширить диапазон вовлекаемых ресурсов эндогенного социально-экономического развития, наращивать преимущества и успешно предотвращать, локализовать и ликвидировать угрозы национальным интересам, ориентируя на повышение готовности к самым разнообразным и парадоксальным проявлениям общественной и индивидуальной жизни ${ }^{16}$.

Так, защита самобытности и своеобразия, нарастание различий и борьба сторон противоречий - условие развития ойкумены. Причём не мускульная энергия, а духовно-интеллектуальное творчество становится определяющим фактором нового мироустройства, средством и целью конкурентной войны. Источник богатства в человеческой одарённости, соответственно, несправедливы как обнищание: относительное и абсолютное, - так и поляризация возможностей доступа к благам общества. Вместе с тем, равенство прав вовсе не означает равенства ответственности, которая резко возрастает с повышением могущества. Наивысшая эффективность творческой (прежде всего, интеллектуальной) активности требует создания условий раскрытия: поиска, просоциальных развития и реализации - наибольшего числа одарённостей в обществе. Посему ценность жизни и возможности творчества прямо зиждутся на равенстве прав и возможностей, распространении социальных

16 Шедяков В.Е. Развитие международных экономических отношений в эпоху постглобализма. Innovative Potential of Socio-Economic Systems: the Challenges of the Global World: Proceed. of III Intern. Scient. Conf. Lisbon, December $28^{\text {th }}, 2018$. P. 11-13. 
и гуманитарных стандартов. Для этого необходимо как принятие на себя государством максимума рутинной суеты, так и отсечение избыточного (потребительского, накопительского) фетишизма с учётом особенностей «малой родины». Необходимость максимизации поля развития задатков и реализации творческой активности ориентирует на оптимизацию роли государства. К примеру, уже и США сами активно отходят от идеологии невмешательства в экономическую жизнь и упования на регулятивные возможности рынка, жёстко заставляя вернуться разбросанные по миру производства и ведя многочисленные торговые войны. Одновременно продолжается политика и открытого силового давления для продвижения своих позиций, в частности - военного обеспечения собственных валютно-банковских, промышленно-хозяйственных, торговых, идеологических и прочих интересов. С одной стороны, сторонниками фритредерства и снятия препон в организации международной жизни всегда были страны-лидеры, получавшие от этого наибольшие выгоды, тогда как протекционизм защищался уязвимыми на данном этапе государствами. С другой, одной из форм эгоцентризма стран, скопивших наибольшие богатства, становится выдвижение ими подходов некоторой самоизоляции с воссозданием черт, напоминающих постулаты протекционизма. Таким образом и выстраивание барьеров между собой и прочими, и требование к другим «открыться» для лидеров представляют собой взаимодополняющие попытки паразитировать на чужих ресурсах. Вместе с тем, поддерживая развитие реальной экономики в своей стране, США пытаются её подчинить в других государствах, расценивая и её как необходимую составляющую суверенитета, и весь мир как совокупность либо орудий своей воли, либо врагов. Отсюда и умножение прокси-столкновений. Для сдерживания конкурентов используется богатая палитра средств, в том числе спекуляции на чувствах (например, при применении сети «зелёных» организаций, гуманитарных интервенций и так далее). В частности, разветвлённая паутина разнообразных неправительственных организаций позволяет тормозить конкурентов под лозунгами, де-факто, злокачественных форм либерализма и империализма.

Период форсированных изменений не только концентрирует в себе многоликость переходных и парадигмальных, формальных и содержательных противоречий, но и требует воспитания: именно в массовом порядке - людей, готовых ответственно сталкиваться в своей повседневной жизни с необходимостью решения задач 
мировоззренческого масштаба и проявлять при этом разумную инициативу ${ }^{17}$. Возросшая мощь человечества может служить как созидательным, так и разрушительным целям. Формирующиеся новые модели устройства должны расширить возможности привлечения к историческому творчеству и найти приемлемые решения наиболее острых антагонизмов. Так, новую актуальность обретает опыт известных инициатив прошлого по коллективному противостоянию политике силы (например, известная «Декларация о вооружённом нейтралитете» XVIII века). В период межпарадигмального перехода на острие противоречий - отстаивание варианта дальнейшего структурирования.

Повышение уровней тесно взаимосвязанных гуманизма и народовластия - необходимость подъёма общественной эффективности. И здесь осознание нравственной самоценности - не менее весомый фактор, нежели технологическое превосходство, социальнополитическая соборность, экономическая динамика или же военная мощь. Приоритетом являются не глобальные связи, а внутреннее развитие по всему диапазону измерений общественной жизни (в частности, внутреннего рынка). Таким образом, возникает представление о новом регионализме как порождении уже глобального этапа международных отношений, когда задачи внутреннего развития подчиняют себе борьбу за внешние рынки (в т.ч. рабочей силы, сырья, технологий и др. - прежде всего, высокотехнологичные). При этом децентрация управления как соответствующая процессам нарастания диффузии знаний, умений и навыков может повысить устойчивость не только системы управления, но и всей общественной целостности, вызывая активизацию иммунных сил социального организма.

\section{2. Культурно-цивилизационные миры - остов ойкумены регионов}

Характерные черты постглобальности, в частности, приоритетная опора на свои силы (прежде всего, вокруг базовых ценностносмысловых комплексов культурно-цивилизационного мира) и сосредоточенность на решении внутренних проблем жизнеустройства и развития, предпочтение эндогенных вариантов оперирования

17 Шедяков В.Е. Вектор постсоветских трансформаций как фактор глобальних преобразований. Economy and Society: the Modern Foundation for Human Development: Proceed. of III Intern. Scient. Conf. Leipzig, April 26 ${ }^{\text {th }}, 2019$. P. 40-41. 
потенциалом, оживление идеалов накопления внутренних созидательных сил общества, разумного протекционизма и самодостаточности, - подталкивает к переоценке геостратегических разграничений (например, и на основе евроскептицизма, роста иных объединений и подходов, трансформации механизмов международного взаимодействия из структур неоимпериализма в формы партнёрства). Самодостаточность и независимость должны не противоречить, а стать базой взаимодействия и полилога. Между тем цели и образы государств и граждан неуниверсальны и зиждутся на базовых ценностно-смысловых комплексах культурно-цивилизационных миров, формирующих собственные традиции учёта разнообразия мнений при обеспечении единства. Переходный межпарадигмальный период - это и «возвращение к себе», и проведение модернизации на своей основе ${ }^{18}$.

При этом полиструктура мирохозяйственных связей как целостность, основанная на выработанных и взаимоприемлемых нормативах отношений, а вовсе не блок из идентичных атомовэлементов, приобретает вид формируемой действительности. Ни одна система ценностей в моделях постмодерного развития и постглобального структурирования уже не может рассматриваться как единственно возможная для человечества ${ }^{19}$. Когда нет стабильной внешней опоры в виде общей идеологии, единой культуры, общепризнанной науки, тогда исчезает понятие периферийной культуры: все они равноценны и равноправны ${ }^{20}$. В этом контексте и само понятие развития нуждается в обновлении: кроме стабильного и сбалансированного роста, оно должно ориентироваться на такие максимы как солидарность, свобода выбора, убеждений и слова, терпимость. И воссоздание ценностно-смысловых комплексов - основа идентичности и условие нормальной жизни. ${ }^{21}$.

Ценностно-смысловые комплексы фиксируют проявление общественного сознания в индивидуальном, потому формируют

${ }^{18}$ Шедяков В.Є. Геостратегія сорозвитку: ціннісно-смислові комплекси як основа взаємодій культурно-цивілізаційних світів. Вісник Дніпропетровського університету. 2015. № 2. С. 217-229.

${ }^{19}$ Castells M. The Power of Identity. The Information Age: Economy, Society and Culture.. Vol. II. Wiley-Blackwell, 2010. 584 p.

${ }^{20}$ Trout J., Rivkin S. Differentiate or Die: Survival in Our Era of Killer Competition. Wiley. 272 p.

${ }^{21}$ Остервальдер А., Пинье И., Бернарда Г., Смитт А. Разработка ценностных предложений. Москва: Альпина Паблишер, 2017. 312 с. 
целостно-социокультурное представление о мире, интегрирующее рациональное и эмоциональное восприятие на социальном уровне информационного воздействия, обеспечивая общность понимания нормы, справедливости, доверия, совести (что всё заметнее реализуется как «совесть», сохранение истины при передаче вести) и так далее. Традиционные ценности культурно-цивилизационных миров сохраняются (в частности, в виде нравственных ориентиров и поведенческих императивов) и у разделённых народов. Ценностносмысловые комплексы реализуются как единство фундаментальных, базовых и актуальных, подвижных слоев. Благодаря этому обеспечивается как социально-политическая устойчивость культурноцивилизационных миров, так и их развитие и приспособление к меняющимся условиям. Вместе с тем, формообразование ценностносмысловых комплексов усиливает возможности разнонаправленного воздействия на них. Причём если утилитарно-прагматические ценности производны от способа производства непосредственно либо через структуры потребностей, то абсолютные ценности, ценностиидеалы влияют на жизнедеятельность как первичные ${ }^{22}$. Соответственно, ценностно-смысловые комплексы складываются и реализуются на двух основных уровнях: мировоззренческом и функциональном, - формируя, соответственно, подсистемы ценностно-мировоззренческих и ценностно-функциональных комплексов, которые отражают, по преимуществу, идеально-духовные и реально-бытовые срезы бытия.

Иерархии же политических ценностей активно участвуют в выработке мотивов активности человека, а в совокупности - его поведенческие характеристики. Культурообразующая роль ценностносмысловых комплексов проявляется в государственных миссии и морали (причём не только взаиморезонируя, но и, порой, противореча друг другу). Как правило, например, представители модерного стиля поведения в большей мере стремятся к самореализации, потому в целом их ценности рационализируются, а они более активны и уверены в себе, тогда как аграрное население традиционных производств больше ориентировано на окружение, конформизм и традиции. Как известно, в организационной культуре

22 Шедяков В.Е. Активизация социально-экономических ресурсов обеспечения общественного согласия в решении стратегических созидательных задач. Інституціалізація як фактор забезпечення розвитку системи інвестиційно-інноваційної безпеки Украӥни / ред. О.Л. Гальцової. Запоріжжя : Гельветика, 2019. С. 242-261. 
и превалирует или агрессивный подход (разрешения и запрещения), или миролюбивый (предписания и заповеди). Эти главенствующие подходы пронизывают системы мировоззрения, ценностей и норм, убеждений и отношений (мифов, обрядов, ритуалов), а соответственно, и восприятия роли изменений, фактора времени, отличий по признакам пола, возраста, этнических особенностей и такое прочее, инициируя доминирование индивидуалистической либо коллективистской культуры (которые зримо отличаются в параметрах отношения к вмешательству в личную жизнь, степени влияния организации на самочувствие каждого, патернализма и расчёте на поддержку группой, иерархическое продвижение - исключительно внутри знакомой среды и соответственно стажу либо как внутри, так и вне в соответствии с компетентностью, дистанционность или сплоченность в социальных коммуникациях, правило «жить, чтобы творить» либо «получать, чтобы потреблять», стремление быть первым или быть как все, тяга к независимости или солидарности, социальная расположенность к успешным или неудачникам, доминирование логики или интуиции при принятии решений и проч.). Соответственно, частота выражения своего несогласия для культуры с высоким уровнем дистанции власти - преимущественно, низкая, тогда как с низким уровнем высокая, предпочитаемый стиль управления в первом случае директивный, во втором - демократический, восприятие неравенства в первом случае, в основном, как неравенства людей, во втором, как неравенства ролей, отношение к представителям аппарата управления «они» или «мы», кардинально меняются также доступность руководства, соотношение права и традиции, архитектоника социальных структур, размеры дифференциации доходов и состояний, многочисленность периферийных социальных групп, степень информированности членов групп, статусность представителей разных групп, поведенческие особенности в связи с отношением к неопределённости среды.

Разумеется, постглобальный мир строится как совокупность взаимозависимых, но кардинально разных культурно-цивилизационных миров - макрорегионов ${ }^{23}$. Но осуществляется не только переход от попыток культуртрегерства к полилогу культур (в том числе социально-политических). Если древние цивилизации были относительно изолированными, то глобализация установила прочную взаимозависимость народов и их социально-политических культур. Но

23 Storper M. The Regional World: Territorial Development in a Global Economy. New York : Guiford Press. 1997. 338 p. 
вот качество этой взаимозависимости может варьироваться. Содержательная, а не формальная («как картофелины в мешке») взаимозависимость связывает именно взаимодополняющие, значит различающиеся, а не тождественные образования. Таким образом, постмодернизация приводит к формированию уже глобально соотносимого, но регионального по своему существу структурирования $^{24}$. Соответственно, новый регионализм и возникает под влиянием как собственных закономерностей трансформирования регионов, так и особенностей новой общественной и техникотехнологической среды ${ }^{25}$. Между тем, децентрализация не должна на деле превращать социально-политические конфликты в территориально-географические и межрегиональные противоречия или же сводиться к искусственной фрагментации народа ${ }^{26}$. Поддержание же Сверхпроектом баланса разнородных социально-политических сил с многообразием их интересов и целей без подавления их особенностей при сохранении продуктивности общества и его развития входит в понимание соборности. Сверхпроект позволяет почувствовать свою индивидуальную сопричастность общественным свершениям, найти «своё место в общем строю», предоставив пути общественно продуктивным развитию и реализации сущностных сил каждого. Таким образом, дальнейшее очеловечивание механизмов жизнедеятельности культурно-цивилизационного мира коррелирует с обеспечением взаиморезонирования процессов индивидуализации и социализации, интеграции и самоценности. Вместе с тем, с одной стороны, создание условий, благоприятных для индивидуального и коллективного творчества, - обязательная черта продуктивного состояния семьи и общества; с другой, предполагается как подстраховка, замена или восстановление общественных связей, становящихся по каким-либо причинам инвалидными, так и иммунное отторжение вредоносных воздействий, предотвращение либо локализация девиаций антиобщественного поведения. Соответственно, для консолидации народа на продуктивных целях Сверхпроект требует динамического подкрепления малыми созидательными проектами. Способность к устойчивости и изменению культурно-цивилизационных миров во многом определяется сплетённостью

${ }^{24}$ Китинг М. Новый регионализм в Европе. Логос. 2003. № 6. С. 18-27.

25 Шедяков В.Е. Новый регионализм: интеграция в условиях постглобализма. Регіональна економіка та управління. 2018. № 3 (21). С. 102-108.

${ }^{26}$ Омае К. Упадок национального государства: становление региональных экономик. Москва : Новый мир, 1999. 290 с. 
(в частности, под влиянием исторического опыта, социокультурного наследия и ментальных матриц народа) объективных и субъективных факторов структурирования, формирующих как разнокачественные обратные связи и отношение к творчеству (индивидуальному и массовому, в труде и управлении), так и основные регулятивные контуры народовластия ${ }^{27}$.

\section{3. Обеспечение национальных интересов в постглобальной среде}

Безопасность и развитие общества обеспечивается функционированием контуров координации и самоуправления, качество которых предопределяет характер ответов социальной целостности на внутренние и внешние вызовы. Освоения комплекса элементов безопасности и развития - основная задача переходного периода ${ }^{28}$. Развитие - условие общественной безопасности. При этом традиции и инновации кажутся противостоящими друг другу в основном при их изолированном рассмотрении и анализе. В движении же функционирования и развития традиции постоянно видоизменяются, порождая новые формы и создавая простор для общественно важных инноваций ${ }^{29}$. Закрепление в обществе инноваций обеспечивается их укоренённостью в традициях, близостью базовым ценностносмысловым комплексам культурно-цивилизационного мира. Соответственно, восстановление традиций в кардинально меняющихся условиях требует переформирования ценностно-смысловых комплексов: в той же степени сохранения, что и изменчивости, адекватного среде, возможностям, рискам и задачам «времени и места».

Место относительно стабильных конфигураций занимают ситуативные альянсы. На наших глазах рассыпается модель однополюсности международных отношений. В исторической

27 Александров Ю.И., Кирдина С.Г. Типы ментальности и институциональные матрицы: мультидисциплинарный подход. Социологические исследования. 2012. № 8. С. 3-13.

28 Шедяков В.Е. Осуществление парадигмальных трансформаций: сорезонирование стратегии, тактики и оперативного искусства в управленческих композициях. Development and modernization of social sciences: experience of Poland and prospects of Ukraine / Maria Curie-Sklodowska University. Lublin: Baltija Publishing, 2017. P. 282-307.

29 Шедяков В.Е. Постсовременная геополитика: социокультурное содержание, региональное измерение. Регион: проблемы и перспективы. 1998. № 2-3. C. 45-53. 
динамике то один, то другой культурно-исторический мир доминировал в международной жизни. Некоторое время на основе освоения модели модерна в её капиталистической версии главенствовали страны Запада (в т.ч., после уничтожения автохтонных цивилизаций аборигенов, его дочерние североамериканское и австралийское ответвления). Однако на смену условной «эре Америки» не приходит эпоха кого-либо другого. Скорее, речь идёт вообще о кардинальном изменении ресурсно-методологических баз развития. При этом динамизм творческого поиска смещается от евроатлантической доминанты к азиатско-тихоокеанскому региону. Причём никакая группа не может быть «независимыми демиургами», a c каждой новой контролирующей инстанцией дополнительно мультиплицируются общественные отношения, в свою очередь выходящие из-под контроля. Наличие органичного комплекса общественных регуляторов - условие прогресса, усложнение этих регуляторов - признак прогресса, необходимость соответствия управляющей системы управляемой целостности. Более того, чем более соответствующим конкретике становится решение, тем более богатый арсенал возможностей оно открывает. Чем больше оснований у региона и общества, чем более сложной является внутренняя структура, тем она более устойчива в периоды и относительной стабильности, и форсированных изменений, тем более способна к развитию ${ }^{30}$.

При этом возникновение новых систем сдержек и противовесов происходит путём многочисленных конфликтов, стимулирующих расползание хаоса $^{31}$. Полицентризм и ризомичность развития заведомо отрицают и единственность «точки сбора» будущего, и общность модели развития ${ }^{32}$. Формируется ряд взаимодействующих (партнёрски и конкурентно) центров, каждый из которых культивирует удобные

${ }^{30}$ Шедяков В.Е. Обеспечение экономического суверенитета: глобализм и регионализм в социально-экономических отношениях. Economy and Management: Modern Transformation in the Age of Globalization: Proceed. of II Intern. Scient. Conf. Klaipeda, March 23 ${ }^{\text {th }}$, 2018. P. 6-8.

${ }^{31}$ Перкинс Д. Исповедь экономического убийцы. Москва : Pretext, 2005. $319 \mathrm{c}$.

32 Шедяков В.Е. Формирование экономического суверенитета страны в условиях перехода к обществу знаний на основе развития научноинтеллектуального потенциала и материально-технической базы. Вісник Одеського національного ун-ту. 2018. Т. 23. Вип. 8 (73). Економіка. С. 8-13. 
для себя варианты структурирования общественной жизни ${ }^{33}$. В обществе знания каждый ответственно делает свой выбор и никто никому ничем не обязан; что неизмеримо поднимает планку требований к нравственности и верности традициям, а, значит, методологии образования и управления ${ }^{34}$. В сложившейся ситуации методология стимулирования желательных изменений составляет адекватный условиям и эпохе регулятивный принцип постсовременности $^{35}$. Между тем, переживание собственного падения как общей катастрофы зачастую провоцирует на истеричные реакции и подталкивает к нерациональным решениям. Реальное осознание ответственности за сохранение планеты и развитие человечества противостоит раскачке международных отношений как в сфере глобальной безопасности, так и в других измерениях жизни. Тем самым в число важнейших для ойкумены задач выходит формирование условий полифонии подходов, полилога акторов при признании их самоценности и равноправия. В свою очередь, это означает необходимость и укрепления рычагов, вынуждающих к выполнению принимаемых на себя обязательств, и признание верховных прав на вмешательство (военное, экономическое, гуманитарное и т.д. - в частности, введение каких-либо санкций) исключительно за $\mathrm{OOH}$ c её Советом Безопасности, а также формируемых совокупностью воль национальных представительств организаций (типа ВТО). Недопустимы ни игнорирование чужих (пусть и вполне правомерных) интересов, ни саботаж демократических механизмов взаимодействия, ни применение мер недобросовестной конкуренции (например, запугивание, подкуп и устранение неудобных для себя лидеров других стран).

Развитие демократии / народовластия и кардинальное усложнение материально-технической базы производства общественной жизни требует адекватного изменений всего социального пространства

33 Газенко Р., Мартынов А. Идеальный шторм. Технология разрушения. Москва: Книжный мир, 2016. 272 с.

34 Шедяков В.Е. Международные экономические отношения: стратегические тенденции. New stages of development of modern science in Ukraine and EU countries / scient. ed. \& project dir. A. Jankovska. Riga : Baltija Publishing, 2019. P. 451-472. DOI: https://doi.org/10.30525/978-9934-588-15-0

35 Шедяков В.Е. Стратегия постсовременного взаимодействия: методология и ресурсная база дальнейшего совершенствования. Нова парадигма. 2014. Вип. 119. С. 34-52. 
социума, всей общественной среды ойкумены ${ }^{36}$. Постсовременное взаимопересечение признаков постиндустриальности и постглобализма и восстанавливает уже во всемирном масштабе эффект агоры, и усиливает искус задействования манипуляций для получения результата и обеспечения трансформаций, расцениваемых как выгодные ${ }^{37}$.

Разумеется, нормативно-экономическое регулирование (на уровнях преследования прагматической выгоды и юридических коллизий) при межпарадигмальной турбулентности недостаточно; в состоянии как возвышать, так и низводить - соответственно целевым установкам, возникающим под влиянием тех же ценностно-смысловых комплексов, которые не только наполняют жизнь, но и оправдывают её. Однако и постглобальная среда создаёт возможности соединить преимущества интеграции в мировые отношения с защитой своеобразия базовых ценностно-смысловых комплексов, закладывающих ось идентичности культурно-цивилизационного мира, и время концентрированной переходности потворствует разнообразию.

Фактором внешнего воздействия на важные политикоэкономические процессы способны стать внутренние субъекты представители правящих групп и формирования общественного мнения. Например, с одной стороны, - граждане иностранных государств, занимающие решающие властные посты, а также приходящие к государственному управлению находившиеся долгое время на оплате у иностранных государств, организаций и частных лиц (т.н. «грантоеды»). С другой стороны, поставляя непроверенные и искажённые данные СМИ могут трансформироваться из средств информирования в средства манипулирования общественным мнением. «Промывание мозгов» несёт угрозу превращения его в важный фактор примитивизации и неоархаизации жизни. При этом, зачастую, подходы «на экспорт» и «для себя» существенно отличаются. В частности, идентичные действия могут представляться то террористическими, то национально-освободительными - в зависимости от оценочного подхода. К примеру, то или иное действие / факт могут либо даваться в ряду огромного числа альтернатив, либо

36 Шедяков В.Е. Ресурсно-методологические базы геостратегического переформатирования. Politicus. 2017. Вип. 3. С. 112-118.

Шедяков В.Е. Культура принятия и реализации решений в гиперконкурентной среде. Development of Socio-Economic Systems in a Global Competitive Environment: Proceed. of II Intern. Scient. Conf. Le Mans, May $24^{\text {th }}$, 2019. P. 149-150. 
как единственно возможные. При этом углубление трансформаций проходит информационный (отдельных фактов и их рядов), концептуальный и ценностно-смысловой уровни.

Акцентирование духовных трансформаций и интеллектоёмкого творчества - условие выживания и развития ойкумены как разнообразия культурно-цивилизационных миров. Между тем, кардинальная демократизация отношений труда, собственности и управления как ответ на изменение среды, вовлечение в процессы регулирования широких масс тружеников ставит задачу их обучения, причем отнюдь на уровне не частных тренингов, а серьёзного подъема концептуального, методологического образовательного уровня. Для гражданского общества совершенно недостаточно профессиональной грамотности, тем более - «натасканности» в решении точечных краткосрочных задач. Сознательная активность и разумная инициатива предполагают наличие институциональных и неинституциональных форм, использующих особенности ризомичности трансформаций сетевых коммуникаций.

Оказывать влияние (тем паче - определяющее) на возникшие глобальные тренды требует замены организационно-управленческих технологий на более эффективные в новых условиях и вовлечения лидеров, работающих в интересах своих культурно-цивилизационных миров $^{38}$. В нынешних условиях неготовность к ответственному выбору ведёт к политике бонапартизма и усиливает угрозу балканизации. Впереди - масса развилок, а в выборе принципиального пути для лимитрофа определяющими по-прежнему будут сугубо внешние интересы. Между тем, в основе выбора - приоритет эгоистических или же более широких общественных интересов. Сегодня наиболее острое противоречие - это антагонизм в реализации созданной базы, которая может использоваться либо для радикальной гуманизации жизни в интересах всего живого, либо для эффективного манипулирования, что и проявляется в противостояниях интересов основных масс народа и олигархата компрадоров. Одним же из острейших противоречий, проявляющихся посредством сонма конфликтов, становится противостояние ценности собственной самобытности (в частности, творческого саморазвития и самоосуществления) и обладания (подчинения, манипулирования). Принадлежность к доминированию каждой из них генерализирует, выстраивает дерево целей - интересов,

38 Мегатренды мирового развития / отв. ред. М.В. Ильин, В.Л. Иноземцев. Москва: Эк-ка, 2001. 295 с. 
функционально-ролевую системность. Применение этих стратегий может быть использовано для успеха и преуспевания либо своего культурно-цивилизационного мира, либо себя, быть ориентировано на социальные или антисоциальные (и асоциальные) задачи. В любом случае, во-первых, если не иметь и не реализовывать стратегии собственного Сверхпроекта, то превращаешься из субъекта процессов в объект внешнего манипулирования. Во-вторых, обеспечение приемлемого качества жизни населения, хозяйственного успеха и долгосрочного стабильного развития в информационную эру возможно только на основе комплексного подъема и обеспечения условий востребованности научно-образовательного комплекса.

Постсоветские преобразования, накладываясь на особенности постиндустриализма, постглобальности и, в целом, постсовременности, порождают существенные модификации социокультурной и политико-экономической среды реформ. Вместе с тем, специфический характер нынешней модернизации предполагает резкое увеличение значения рефлексивных и бесструктурных свойств многоканальности эффективного управления. Тем самым, инверсионность проведения перемен, с одной стороны, требует вовлечения широких масс трудящихся в процессы осуществления управления, с другой, - акцентирует роль государства в оптимизации безопасности и развития общества ${ }^{39}$. Так, без обеспечения научного уровня методологического обеспечения соучастие в управлении бессмысленно и аморально. Более того, именно отсутствие условий развития и реализации своей комбинации одарённостей способствует наполнению участниками протестных движений, а в конечном итоге и срыву постмодерна в архаику контрмодерна. И проблема не в наличии у человека биофизиологических потребностей, а в их социокультурном гипертрофировании с целью манипулирования индивидуальным и общественным сознанием, оскотиниванием человека и расчеловечиванием общества, облегчением управления толпой, «заряжённой» на простейшие рефлексы и редукцией к «хлебу и зрелищам» наших дней.

\section{ВЫВОДЫ}

После Второй мировой войны установились модель и порядок международной жизни, основанные на нерушимости границ, зафиксированной в ялтинских, потсдамских, наконец, хельсинкских

\footnotetext{
${ }^{39}$ Гринспен А. Эпоха потрясений. Москва : Юнайтед Пресс, 2010. 550 с.
} 
договорённостях. Баланс был нарушен с ликвидацией ГДР, СССР, СФРЮ, ОВД и лагеря реального социализма; начался поиск других основ миропорядка. Некоторое время держалась гегемония как Запада во главе с США, так и его модели жизнеустройства. Ныне заметно, что на смену ей идёт не победа геополитического соперника, не иная модель навязывания, а конкурирование совершенно ранных моделей и подходов, прежде всего - вокруг культурно-цивилизационных миров). Соответственно, необходимо комплексное создание условий не просто для внедрения передовых технико-технологических укладов, но для просоциальных развития и реализации человеком своих способностей, передачи им обществу лучших из возможных жизненных стратегий.

Вместе с тем, как мюнхенский сговор сделал неизбежной перенос «большой войны» в Европу, так закрепление международного права Нюрнбергом и ялтинско-хельсинкскими договорённостями сделало их стержнем мира после II Мировой. Отказ же от принципа нерушимости границ, проявившийся, в частности, в разделе Югославии, усилил предпосылки и дал мощный толчок большого переструктурирования и нового дробления / собирания сил. Заметно, что ныне в первую очередь, свои подходы пытаются репрезентовать и отстоять Китай и РФ, Индия и Пакистан, Иран и Турция, США и Европа. У стран Запада, разумеется, не больше прав, чем у любых других. Однако, накопленная ими мощь и пути её достижения (в частности, ограбление колоний и работорговля) вынуждают к возложению на них гораздо большей ответственности и, соответственно, спросу с них. Между тем, колониальное мышление ещё пробивается как в стратегическом высокомерии, так и в безразличии к судьбам иных цивилизаций, их национальным интересам. Так, освоение их богатств происходило с геноцидом местного населения - как, например, земель Нового света европейцами. Пренебрежение Запада к правам, культуре и истории системно проявляется не только в дестабилизации, а то и оккупации стран и целых регионов (например, в Исламском мире или же в Латинской Америке), но и в варварском внесении в список целей, обречённых на уничтожение, артефактов культуры уровня общемирового достояния.

При этом западная модель общественного устройства и миропорядка во многом исчерпала себя, распадаясь на вариации и стилистики подходов. Застарелые боязнь и неверие своему народу консервируют пережитки феодализма, например, в Британии (где народ напрочь отсечен от избрания даже премьер-министра) и рабовладения в США (коллегия выборщиков искажает 
действительный выбор нации). Тем паче беспочвенно и нереалистично стремление стран из бывшего «лагеря реального социализма» попасть в «золотой миллиард». На переломе межпарадигмального уровня «каждый сам вытаскивает себя за волосы из болота». Вместе с тем, очевидна естественная заинтересованность Украины не только в укреплении добрососедских отношений, прежде всего, с Европой и Россией, но и таких же всесторонних взаимовыгодных и комплементарных контактов между ними - как минимум, это условие стратегической транзитной востребованности. Новый этап мировой конкуренции стартовал с уходом либерал-глобализма (в частности, евро-американского) с передовых позиций и выходом на авансцену новых игроков. Соответственно, изменившиеся реалии ведут к иным соглашениям: и «один на один», и в обустройстве международной жизни. У каждого народа, всякого культурно-цивилизационного мира при этом - свои «козыри», своя комбинация угроз и возможностей, свои особенности ресурсно-методологических баз. Навязывание доминирования своих «правил игры» с перетаскиванием на удобный для себя плацдарм противостояния - естественное средство облегчения победы $^{40}$. Так что конфронтационный подход заведомо лицемерен и предполагает разные стратегии: для других - экспансия, для внутреннего потребления - поддержание гармонии. При этом, с одной стороны, секрет успеха народа - в привязке общих тенденций к своим конкретным условиям. С другой, кардинальное значение приобретает соединение государственного управления с местным самоуправлением в принятии от населения рутинно-бытовых проблем для расковывания просоциального вектора творческой активности народа. Разумеется, условиями этого становится создание условий как трудовой детерминанты материального благополучия и социального статуса, так и восстановления практической реализации представлений о справедливости порядка. Многовариантность развития событий повышает заинтересованность в усилении удобных для себя характеристик. Свои представления не только об устройстве собственной общественной жизни и приватного сектора, но и об определяющих чертах формирующейся новой реальности активно вырабатывают с позиций разных мировоззрений. Активизировались не столько ресурсы глобального и национального консенсуса, сколько партии социального возмущения: «правые» и «левые силы», - тогда

40 Фулбрайт Дж.У. Самонадеянность силы. Мо сква: Международные отношения, 1967. 255 с. 
как в «центре» усилились деидеологизированные «зелёные», часто финансируемые и отстаивающие интересы американских группировок. В то же время США вышли из соглашения по климату, продолжая активно натравливать «зелёные» организации на конкурентов для притормаживания их под идеологемами «либерального доктринёрства». В данный момент Украина не перенимает полностью ни одну из лидерских систем. Более того, её вхождение в любую из них несёт столь серьёзный дополнительный потенциал изменений каждой, что это может и обогатить, и разрушить базовую модель. Соответственно, в элитах всяких лидерских групп существуют весомые опасения и ни в одной из них нет желания прямого включения Украины, но есть в той или иной форме желания манипулирования ею. В восприятии нового на перепутье нравственность народа и политика элиты, качество институтов и лидеров тесно связаны. Сочетание охлократии и олигархата удобно для осуществления внешнего управления и ведёт к умножению явных признаков утраты реального суверенитета. Стремление части населения стран из бывшего «лагеря реального социализма» вхождения их государств в «золотой миллиард» не только беспочвенно и иллюзорно, но и мешает культивированию собственных, оптимальных в данной общественной среде, структурных форм развития и безопасности.

Успешность проведения многоплановых и разноскоростных трансформаций (среди которых есть и кардинальные) настоятельно требует, с одной стороны, комплексности преобразований, с другой, выделения приоритетных направлений (в частности, посредством концентрации ресурсных баз и смещения ресурсно-методологических баз воздействия). Постсовременная продуктивность формируется вокруг творческих возможностей и интеллектуального потенциала человека, их организации и использования. Однако кардинальные трансформации нашего времени, а также глобальный масштаб кризисных явлений безотлагательно требуют дополнительного внимания к изменениям человеческого капитала, в том числе под влиянием новых процессов и тенденций. Таким образом, человечество переживает смену парадигм своей жизнедеятельности и моделей развития. Длительная эпоха приоритета гонки за уровнем удовлетворения растущих материальных потребностей на базе расходования простого труда зримо выявила свои пределы, связанные с неравномерностью концентрации возможностей и угрозами всей планетарной экосистеме. Непременное условие как социального оптимизма вообще, так и достойного участия в международной жизни 
в частности - развитие личности, повышение ценности жизни и возможностей творчества. Причём достигнутый уровень совокупного физического и ментального потребления и выделяемых отходов, характерный для привилегированных регионов, даже близко не может быть распространён на всех из-за уровня давления на среду обитания, однако и сохранять обособленные анклавы комфортной жизни среди эксплуатируемых ради этого регионов всё сложнее, прежде всего, - изза процессов природной и социальной диффузии.

\section{АННОТАЦИЯ}

Международная жизнь рассматривается сквозь призму межпарадигмальных трансформаций. В числе их примет выделен переход от универсализма к разнообразию. В качестве одного из уровней нарастания многоликости международной жизни специальное внимание обращается на повышение значимости её регионального структурирования. Среди процессов региональной организации выделено взаимодействие культурно-цивилизационных миров. Показано, что структурирование международной жизни полилогом культурно-цивилизационных миров требует адекватного развития не только нормативных и социально-экономических, но и духовнонравственных практик, что смещает акценты не только в организационном умении, но и в образовательно-педагогическом обеспечении ценностно-смыслового подъёма. Потому как непременное условие и социального оптимизма вообще, и достойного участия в международной жизни в частности рассмотрено создание условий развития личности, что связывается с повышением ценности жизни и возможностей творчества. Продуктивные организационноуправленческие (в частности, психолого-педагогические) инновации ориентированы на более полное раскрытие индивидуальной одарённости человека и связаны с гуманизацией механизмов реализации публичных и приватных интересов в формах соборности и партнёрства вокруг базовых общественных ценностно-смысловых комплексов.

\section{ЛИТЕРАТУРА}

1. Энгель У. Боги денег. Уолл-стрит и смерть американского века. Санкт-Петербург : Питер, 2011.326 с.

2. Кобяков А.Б., Хазин М.Л. Закат империи доллара и конец «Рах Americana». Москва : Вече, 2003. 368 с. 
3. Engdahl F.W. A Century of War: Anglo-American Oil Politics and the New World Order. Pluto Press, 2004. 312 p.

4. Gamble A. Crisis Without End? The Unravelling of Western Prosperity. UK : Palgrave Macmillan, 2014. 240 p.

5. Фурсов А.И., Правосудов С.А. На пороге глобального хаоса. Битва за будущее. Москва : Книжный мир, 2015. 288 с.

6. Хамел Г., Прахалад К. Конкурируя за будущее. Москва : ОлимпБизнес, 2002. 216 c.

7. Блэквилл Р., Харрис Дж.М. Война иными средствами. Москва : АCT, 2017. $480 \mathrm{c}$.

8. Откуда исходит угроза миру. Москва : Воениздат ; Прогресс ; АПН. 3-е изд. 1984.96 с.

9. Калаич Д. Третья мировая война. Москва : Литератор, 1995. $156 \mathrm{c}$.

10. Амин С. Вирус либерализма: перманентная война и американизация мир. Москва: Европа, 2007. 162, [6] с.

11. Шедяков В.Е. Возможности и риски эпохи: научноисследовательская рефлексия - рефлексивное управление рефлексивная модернизация. Management of modern socio-economic systems / ed. by J. Žukovskis, K. Shaposhnykov. Kaunas: Baltija Publishing, 2017. Vol. 1. P. 201-218.

12. Швейцер П. Тайная стратегия развала СССР. Москва : Эксмо: Алгоритм, 2010. 304 с.

13. Burns T.R., Dietz T. Revolution: An Evolutionary Perspective. International Sociology. 2002, dec. Vol. 16. № 4. P. 531-555.

14. Шедяков В.Е. Парадигмальный переход в теории и на практике: стратегический дизайн форсированных трансформаций. Науковий вісник Херсонського державного ун-ту. Економічні науки. 2017. Вип. 23. Ч. 1. С. $54-58$.

15. Шедяков В.Е. Постглобализм как социально-экономическое явление. Pyxes. 2016. № 4. С. 104-114.

16. Шедяков В.Е. Развитие международных экономических отношений в эпоху постглобализма. Innovative Potential of SocioEconomic Systems: the Challenges of the Global World: Proceed. of III Intern. Scient. Conf. Lisbon, December $28^{\text {th }}, 2018$. P. 11-13.

17. Шедяков В.Е. Вектор постсоветских трансформаций как фактор глобальних преобразований. Economy and Society: the Modern Foundation for Human Development: Proceed. of III Intern. Scient. Conf. Leipzig, April 26 ${ }^{\text {th }}, 2019$. P. 40-41. 
18. Шедяков В.С. Геостратегія сорозвитку: ціннісно-смислові комплекси як основа взаємодій культурно-цивілізаційних світів. Вісник Дніпропетровського університету. 2015. № 2. С. 217-229.

19. Castells M. The Power of Identity. The Information Age: Economy, Society and Culture. Vol. II. Wiley-Blackwell, 2010. 584 p.

20. Trout J., Rivkin S. Differentiate or Die: Survival in Our Era of Killer Competition. Wiley. 272 p.

21. Остервальдер А., Пинье И., Бернарда Г., Смитт А. Разработка ценностных предложений. Москва: Альпина Паблишер, 2017. 312 с.

22. Шедяков В.Е. Активизация социально-экономических ресурсов обеспечения общественного согласия в решении стратегических созидательных задач. Інституиіалізачія як фактор забезпечення розвитку системи інвестиційно-інноваційної безпеки Украйни / ред. О.Л. Гальцової. Запоріжжя: Гельветика, 2019. С. 242-261.

23. Storper M. The Regional World: Territorial Development in a Global Economy. New York: Guiford Press. 1997. 338 p.

24. Китинг М. Новый регионализм в Европе. Логос. 2003. № 6. C. $18-27$.

25. Шедяков В.Е. Новый регионализм: интеграция в условиях постглобализма. Регіональна економіка та управління. 2018. № 3 (21). C. $102-108$.

26. Омае К. Упадок национального государства: становление региональных экономик. Москва: Новый мир, 1999. 290 с.

27. Александров Ю.И., Кирдина С.Г. Типы ментальности и институциональные матрицы: мультидисциплинарный подход. Соииологические исследования. 2012. № 8. С. 3-13.

28. Шедяков В.Е. Постсовременная геополитика: социокультурное содержание, региональное измерение. Регион: проблемы и перспективы. 1998. № 2-3. С. 45-53.

29. Шедяков В.Е. Осуществление парадигмальных трансформаций: сорезонирование стратегии, тактики и оперативного искусства в управленческих композициях. Development and modernization of social sciences: experience of Poland and prospects of Ukraine / Maria CurieSklodowska University. Lublin : Baltija Publishing, 2017. P. 282-307.

30. Шедяков В.Е. Обеспечение экономического суверенитета: глобализм и регионализм в социально-экономических отношениях. Economy and Management: Modern Transformation in the Age of Globalization: Proceed. of II Intern. Scient. Conf. Klaipeda, March $23^{\text {th }}$, 2018. P. 6-8. 
31. Перкинс Д. Исповедь экономического убийцы. Москва : Pretext, 2005. $319 \mathrm{c}$.

32. Шедяков В.Е. Формирование экономического суверенитета страны в условиях перехода к обществу знаний на основе развития научно-интеллектуального потенциала и материально-технической базы. Вісник Одеського національного ун-ту. 2018. Т. 23. Вип. 8 (73). Економіка. С. 8-13.

33. Газенко Р., Мартынов А. Идеальный шторм. Технология разрушения. Москва : Книжный мир, 2016. 272 с.

34. Шедяков В.Е. Международные экономические отношения: стратегические тенденции. New stages of development of modern science in Ukraine and EU countries / scient. ed. \& project dir. A. Jankovska. Riga: Baltija Publishing, 2019. P. 451-472. DOI: https://doi.org/10.30525/9789934-588-15-0.

35. Шедяков В.Е. Стратегия постсовременного взаимодействия: методология и ресурсная база дальнейшего совершенствования. Нова парадигма. 2014. Вип. 119. С. 34-52.

36. Шедяков В.Е. Ресурсно-методологические базы геостратегического переформатирования. Politicus. 2017. Вип. 3. С. 112-118.

37. Шедяков В.Е. Культура принятия и реализации решений в гиперконкурентной среде. Development of Socio-Economic Systems in a Global Competitive Environment: Proceed. of II Intern. Scient. Conf. Le Mans, May $24^{\text {th }}, 2019$. P. 149-150.

38. Мегатренды мирового развития / отв. ред. М.В. Ильин, В.Л. Иноземцев. Москва : Эк-ка, 2001. 295 с.

39. Гринспен А. Эпоха потрясений. Москва : Юнайтед Пресс, 2010. $550 \mathrm{c}$.

40. Фулбрайт Дж. У. Самонадеянность силы. Москва : Международные отношения, 1967. 255 с.

Information about author: Shedyakov V. E., Doctor of Sociological Sciences, Candidate of Economic Sciences, Free-lance Kyiv, Ukraine 